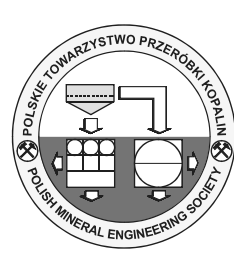

\title{
A Study of PM 10, PM 2.5 Concentrations in the Atmospheric Air in Kraków, Poland
}

\author{
Maciej CIEPIELA', Wiktoria SOBCZYK ${ }^{2)}$
}

\begin{abstract}
1) Department of Environmental Engineering, Faculty of Mining and Geoengineering, AGH University of Science and Technology, 30059 Kraków, Poland; ORCID: 0000-0003-0362-8461; email: ciepiela@agh.edu.pl; correspondence author: maciepiela@gmail.com 2) Department of Environmental Engineering, Faculty of Mining and Geoengineering, AGH University of Science and Technology, 30059 Kraków, Poland; ORCID: 0000-0003-2082-9644 email: sobczyk@agh.edu.pl
\end{abstract}

http://doi.org/10.29227/IM-2021-01-17

Submission date: 13-01-2021 | Review date: 23-05-2021

\section{Abstract}

The air in Kraków is one of the most polluted in Europe. Polish standards for notification and alert levels for PM10 particulate matter are one of the the highest in Europe and exceed the recommendations of the World Health Organization (WHO) for safe daily concentrations by several times. The article presents the results of airborne dust measurements in three districts of Kraków. The study has shown that the concentration of PM2.5 and PM10 particulate matter exceeded the annual average permissible levels. Empirical measurements of PM2.5 show significantly higher air pollution values than the data notified by stationary monitoring stations installed in two locations. The high value of Pearson linear correlation coefficient confirms that weather conditions have a significant impact on air quality in Kraków. Wind speed in the autumn and winter seasons has by far the greatest influence on air quality in al. Krasińskiego, in the Ruczaj and Kurdwanów districts. A strong negative correlation was displayed. Manual measurements should be used to verify data obtained from air monitoring stations. It is to be expected that, in Kraków, air purity will improve due to the implementation of an anti-smog resolution and subsidies for the replacement of obsolete heating systems with more environmentally friendly solutions.

Keywords: particulate matter, air quality, pollution, Kraków

\section{Introduction}

In the 21 st century, the problem of human pressure on the environment has become a major issue. As a result of population growth, urbanization, industrial development and communication boost, the demand for energy and natural resources has increased. This has caused the growing concentration of pollutants introduced into the natural environment, especially into the air. The increase in the emission of pollutants from anthropogenic sources has forced national and international authorities to adopt stringent regulations. Through environmental monitoring, the society can stay informed about any threats emerging when the airborne pollutant standards are being surpassed.

Commission Directive (EU) 2015/1480 of 28 August 2015 amending several annexes to Directives 2004/107/EC and 2008/50/EC of the European Parliament and of the Council, laying down the rules concerning reference methods, data validation and location of sampling points for the assessment of ambient air quality, is an important document regulating low-stack emissions [1]. Suspended particulate matter was included in the group of pollutants with harmful effect on human health. It was agreed that information on the state of air quality must be available to the public.

In Poland, the basic legal act pertaining to air quality is the Act of 27 April 2001 Environmental Protection Law [2]. The law defines the principles of using the environment and protecting its components. Air protection programs aim to improve air quality and achieve specific levels of concentration of harmful substances. The Environmental Protection Law has been amended several times, for example the Act of 10 September 2015 [3] gives the provincial assemblies the possibility to introduce restrictions and bans on the operation of heating installations, in particular furnaces, boilers and fireplaces where solid fuels are burned. This applies to installations supplying heat to a central heating systems or directly releasing heat [2].

Under the amended Environmental Protection Law, the Małopolska Region Assembly adopted Resolution No. XXXII/452/17 of 23 January 2017 on the introduction of restrictions and bans on the operation of installations in which fuels are burned, the so-called antismog resolution [4]. For Kraków, it stipulated a ban on the use of poor quality solid fuels from July 1, 2019 to August 31, 2019. The limitation concerned biomass with humidity exceeding $20 \%$ and coal with grain size up to $5 \mathrm{~mm}$ constituting $5 \%$ of fuel, ash content above $10 \%$, sulfur content above $8 \%$ and calorific value below $26 \mathrm{MJ} / \mathrm{kg}$. In turn, as of September 1, 2019, a total ban on burning solid fuels in stoves, boilers and fireplaces has been in effect in Kraków. The only permissible fuels are natural gas or light fuel oil. Moreover, it is forbidden to smoke bonfires and use stationary barbecues [5].

With regard to energy efficiency, the European regulations have been implemented into Polish law by the Energy Efficiency Act of 20 May 2016 (Journal of Laws of 2016 item 831) [6]. Municipalities and local authorities are obligated to apply at least one solution improving energy efficiency. Examples of such measures are: investments in new installations and equipment, modernization of old installations, implementation of the EMAS environmental management system [2].

\section{Particulate matter concentration standards}

The permissible level, or air quality standard [7], is the concentration of a substance that can be reached in a given period of time and should not be exceeded after that time. 
Tab. 1. Permissible levels for particulate pollutants present in the air [8]

Tab. 1. Dopuszczalne poziomy zanieczyszczeń pyłowych w powietrzu [8]

\begin{tabular}{|c|c|c|c|}
\hline $\begin{array}{c}\text { Name of } \\
\text { substance }\end{array}$ & Averaging period & $\begin{array}{c}\text { Permissible level in the } \\
\text { air in } \mathbf{2 0 2 0}\left[\mathbf{~} \mathbf{m g} / \mathbf{m}^{\mathbf{3}}\right]\end{array}$ & $\begin{array}{c}\text { Permissible annual } \\
\text { frequency of exceeding } \\
\text { the level }\end{array}$ \\
\hline $\begin{array}{c}\text { particulate matter } \\
\text { PM 2.5 }\end{array}$ & Calendar year & 20 & - \\
\hline $\begin{array}{c}\text { particulate matter } \\
\text { PM10 }\end{array}$ & 24 hours & 50 & 35 times \\
\cline { 2 - 4 } & Calendar year & 40 & - \\
\hline
\end{tabular}

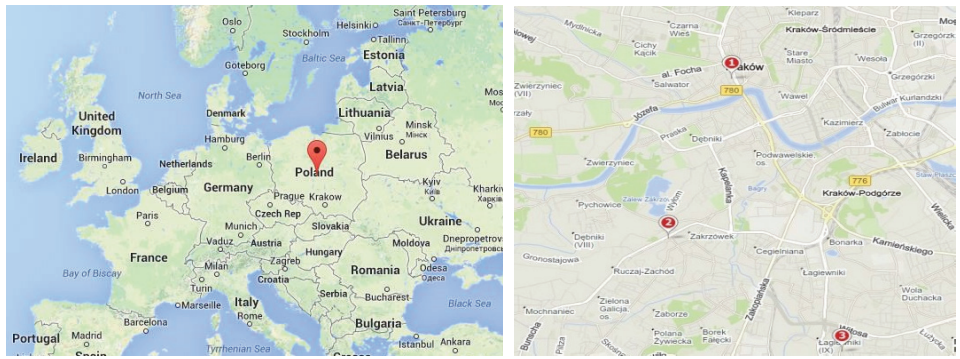

Fig. 1. Location of measurement points (Kraków. 1- al. Krasińskiego, 2- Ruczaj, 3- Kurdwanów) [13]

Fig. 1. Lokalizacja punktów pomiarowych (Kraków. 1- aleja Krasińskiego, 2- Ruczaj, 3- Kurdwanów) [13]

The information level is the level of the substance in the air above which there is a risk to human health from brief exposure to pollutants of vulnerable population groups. The information level for PM2.5 is $150 \mu \mathrm{g} / \mathrm{m}^{3}$, the averaging period is 24 hours, the information level for PM10 is $100 \mu \mathrm{g} / \mathrm{m}^{3}$, the averaging period is 24 hours [8]. The alarm level is the concentration of a substance in the air which, if exceeded in the short term, could cause a hazard to human health $[9,10,11]$.

The admissible concentration standards are the same throughout the European Union, but the notification and alarm levels are treated individually, as their values are not specified in the laws. In a controversial approach, the Polish 24-hour standards for PM10: notification $\left(100 \mu \mathrm{g} / \mathrm{m}^{3}\right)$ and alarming $\left(150 \mu \mathrm{g} / \mathrm{m}^{3}\right)$ are the highest in Europe. Alarming standards exceed the recommendations of the World Health Organization (WHO) for safe daily concentrations [12] by three times.

\section{Methodology and Experimentals}

The study was conducted in three stations located in Kraków (fig. 1): on the border of district I Stare Miasto and VII Zwierzyniec, as well as in districts VIII Dębniki and XI Podgórze Duchackie. The choice of location of measuring points was determined by two factors:

- the presence of measuring stations of the Voivodeship Inspectorate for Environmental Protection in Kraków in the case of the location of stations no. 1 in aleja Zygmunta Krasińskiego and no. 3 Kurdwanów, in order to compare the results;

- the absence of a measuring station in the Ruczaj area (station no. 2), to inform the residents and students of the Jagiellonian University about the particulate matter levels.

The research was conducted from July 23, 2018 to March 6, 2019. The WP6130 dust meter, equipped with PM10 and PM2.5 particulate matter concentration (in the range of 0-999 $\mu \mathrm{g} / \mathrm{m}^{3}$ ), air temperature and humidity detectors was used as the measurement tool. The device is equipped with airborne formaldehyde and volatile organic compound concentration detectors. Measurements were taken once a day in real time and then were compared with measurements for a 24 -hour averaging time. Readings were taken after the results were stabilized 20 seconds after the device was turned on.

At the same time, meteorological data was taken from the AccuWeather online platform for individual measuring stations [14]. The data consisted of the following parameters: PM 2.5 and PM 10 particulate matter, cloudiness, relative humidity, air temperature, wind speed and direction, precipitation and atmospheric pressure.

The measurements of concentrations of PM2.5 and PM10 particulate matter in al. Krasińskiego in Kraków were taken in the following periods:

- in the summer: from July 23, 2018 to September 18, 2018;

- in the autumn: from September 26, 2018 to October 26, 2018 (Fig. 2);

- in the winter: from January 18, 2019 to March 06, 2019 (Fig. 2).

The highest dust concentration was recorded on February 1, 2019, when PM2.5 was $146 \mu \mathrm{g} / \mathrm{m}^{3}$ and PM10 was $163 \mu \mathrm{g} / \mathrm{m}^{3}$. The lowest concentration was recorded on October 24, 2018, when: PM2.5 was $5 \mu \mathrm{g} / \mathrm{m}^{3}$ and PM10 was $7 \mu \mathrm{g} / \mathrm{m}^{3}$. In addition, the weather conditions for the current measurement hour are marked. Cloudiness ranged from: $0 \%$ to $88 \%$ in the summer, from $9 \%$ to $90 \%$ in autumn, from $0 \%$ to $98 \%$ in the winter. According to the weather forecast, relative humidity oscillated between $42 \%$ and $84 \%$ in the summer, between $42 \%$ and $77 \%$ in autumn, between $36 \%$ and $99 \%$ in the winter. According to the weather forecast, air temperature was: from $19^{\circ} \mathrm{C}$ to $30^{\circ} \mathrm{C}$ in the summer, from $8^{\circ} \mathrm{C}$ to $21^{\circ} \mathrm{C}$ in autumn, from $-6^{\circ} \mathrm{C}$ to $17^{\circ} \mathrm{C}$ in winter. Wind speed was: $4-20 \mathrm{~km} / \mathrm{h}$ in the summer, $7-41 \mathrm{~km} / \mathrm{h}$ in autumn, and $4-43 \mathrm{~km} / \mathrm{h}$ in the winter. Precipitation of maximum $2 \mathrm{~mm}$ was recorded on three days only. Atmospheric pressure ranged from $101.00 \mathrm{kPa}$ to $102.40 \mathrm{kPa}$ in the summer, from $100.50 \mathrm{kPa}$ to $103.60 \mathrm{kPa}$ in autumn, and from $100.00 \mathrm{kPa}$ to $103.30 \mathrm{kPa}$ in the winter. 


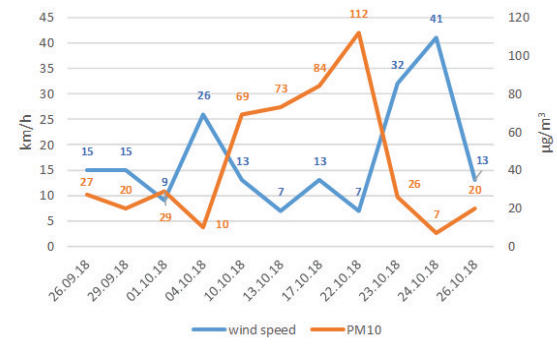

Fig. 2. Graphic illustration of PM10 and wind speed measurements - autumn. Al. Krasińskiego in Krakow Fig. 2. Ilustracja graficzna wyników pomiarów PM10 i prędkości wiatru - jesień. Aleja Krasińskiego w Krakowie

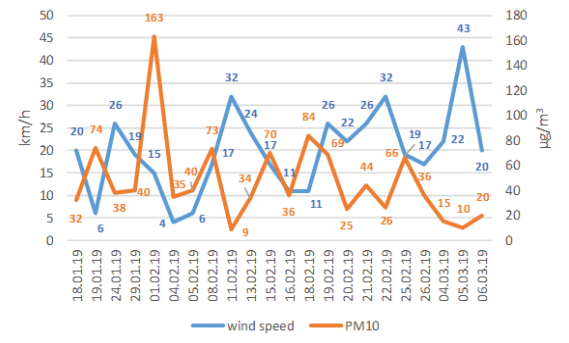

Fig. 3. Graphic illustration of PM10 and wind speed measurements - winter. Al. Krasińskiego in Krakow Fig. 3. Ilustracja graficzna wyników pomiarów PM10 i prędkości wiatru - zima. Aleja Krasińskiego w Krakowie

At the monitoring station in al. Krasińskiego, the permissible PM10 particulate matter concentration was exceeded 21 times, reporting the value of $50 \mu \mathrm{g} / \mathrm{m} 3$ in a 24 -hour standardized result period, whereas in Kurdwanów, this level was exceeded 15 times $[15,16]$. Comparing the PM2.5 readings taken by the dust meter and by the monitoring station, it may be claimed that both in al. Krasińskiego and in Kurdwanów, the dust meter showed significantly higher contamination. In the case of PM10 particulate matter, the difference between dust meter measurements and monitoring station measurements is not statistically significant and may result from measurement error.

\section{Results}

The Pearson linear correlation coefficient (rxy) [17], applied in the study of the straight-line correlation between two variables of normal or symmetrical distribution, was used in the study. The calculated Pearson correlation coefficient for the parameters measured in al. Krasińskiego in Kraków is presented in table 2 .

In summer, a moderate positive correlation was identified between particulate matter concentrations and relative air humidity (0.51), as well as a weak positive correlation between particulate matter concentration and atmospheric pressure (0.36). Moreover, a moderate negative correlation between air temperature and particulate matter concentration was noted (-0.55). In autumn, a moderate negative correlation was found between cloudiness (-0.57) and particulate matter concentration, and a strong negative correlation between wind speed $(-0.63)$ and particulate matter concentration. In addition, there is a moderate positive correlation between air temperature and particulate matter concentration (0.51). In the winter, a moderate negative correlation between wind speed and particulate matter concentration was noted $(-0.41)$.

Table 3 presents the rxy coefficient for the values of the parameters recorded in Ruczaj in Kraków.
In summer, a moderate positive correlation was identified between particulate matter concentrations and relative air humidity (0.50), as well as a moderate negative correlation between particulate matter concentration and air temperature $(-0.45)$. In the autumn, a strong negative correlation between wind speed and particulate matter concentration can be seen $(-0.77)$, as well as a strong negative correlation between cloudiness and particulate matter concentration (-0.62). Furthermore, there was a moderate positive correlation between air temperature and particulate matter concentration (0.53). In the winter, a weak negative correlation between wind speed and particulate matter concentration (-0.39) was observed.

Table 4 presents Pearson correlation coefficients obtained for values of particular parameters in Kurdwanów.

In the summer period, a weak positive correlation between particulate matter concentration and relative air humidity (0.35) and a weak negative correlation between particulate matter concentration and air temperature $(-0.35)$ were recorded. In autumn, on the other hand, a weak positive correlation was reported between particulate matter concentration and relative air humidity (0.36) and a weak positive correlation between particulate matter concentration and air temperature (0.38). In addition, there was a strong negative correlation between particulate matter concentration and wind speed (-0.68), and a moderate negative correlation between particulate matter concentration and cloudiness $(-0.44)$. In the winter, a moderate negative correlation between particulate matter concentration and wind speed can be seen $(-0.55)$ and a weak negative correlation between particulate matter concentration and cloudiness $(-0.35)$.

\section{Disscussion}

Pro-environmental activities depend on local government bodies. The methods of preventing dust emission are associated with legal as well as technical and organizational lim- 
Tab. 2. Pearson's correlation coefficients for the values of individual parameters. Al. Krasińskiego in Krakow Tab. 2. Współczynniki korelacji Pearsona dla wartości poszczególnych parametrów przy al. Krasińskiego w Krakowie

\begin{tabular}{|c|c|c|c|c|c|c|}
\hline & & Cloudy & Humidity & Temperature & Wind speed & Air pressure \\
\hline \multirow{2}{*}{ 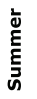 } & PM2.5 & $-0,04$ & 0,51 & $-0,55$ & $-0,12$ & 0,36 \\
\hline & PM10 & $-0,05$ & 0,52 & $-0,54$ & $-0,12$ & 0,36 \\
\hline \multirow{2}{*}{ 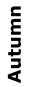 } & PM2.5 & $-0,57$ & 0,29 & 0,51 & $-0,63$ & 0,26 \\
\hline & PM10 & $-0,57$ & 0,29 & 0,51 & $-0,63$ & 0,25 \\
\hline \multirow{2}{*}{$\frac{\stackrel{2}{ \pm}}{\frac{ \pm}{3}}$} & PM2.5 & $-0,25$ & 0,18 & $-0,16$ & $-0,40$ & $-0,02$ \\
\hline & PM10 & $-0,25$ & 0,18 & $-0,16$ & $-0,41$ & $-0,03$ \\
\hline
\end{tabular}

Tab. 3. Pearson's correlation coefficients for the values of individual parameters. Ruczaj Tab. 3. Współczynniki korelacji Pearsona dla wartości poszczególnych parametrów. Ruczaj

\begin{tabular}{|c|c|c|c|c|c|c|}
\hline & & Cloudy & Humidity & Temperature & Wind speed & Air pressure \\
\hline \multirow{2}{*}{ 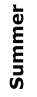 } & PM2.5 & 0,22 & 0,50 & $-0,45$ & 0,02 & 0,18 \\
\hline & PM10 & 0,19 & 0,47 & $-0,43$ & 0,01 & 0,18 \\
\hline \multirow{2}{*}{ 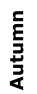 } & PM2.5 & $-0,62$ & 0,01 & 0,53 & $-0,77$ & 0,21 \\
\hline & PM10 & $-0,62$ & 0,01 & 0,53 & $-0,77$ & 0,21 \\
\hline \multirow{2}{*}{ 离 } & PM2.5 & $-0,27$ & 0,18 & $-0,09$ & $-0,39$ & $-0,06$ \\
\hline & PM10 & $-0,27$ & 0,18 & $-0,09$ & $-0,39$ & $-0,07$ \\
\hline
\end{tabular}

Tab. 4. Pearson's correlation coefficients for the values of individual parameters. Kurdwanów Tab. 4. Współczynniki korelacji Pearsona dla wartości poszczególnych parametrów. Kurdwanów

\begin{tabular}{|c|c|c|c|c|c|c|}
\hline & & Cloudy & Humidity & Temperature & Wind speed & Air pressure \\
\hline \multirow{2}{*}{ 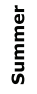 } & PM2.5 & 0,27 & 0,35 & $-0,35$ & $-0,17$ & 0,10 \\
\hline & PM10 & 0,28 & 0,33 & $-0,33$ & $-0,14$ & 0,08 \\
\hline \multirow{2}{*}{ 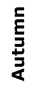 } & PM2.5 & $-0,44$ & 0,36 & 0,38 & $-0,68$ & 0,26 \\
\hline & PM10 & $-0,44$ & 0,36 & 0,38 & $-0,67$ & 0,26 \\
\hline \multirow{2}{*}{ 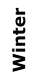 } & PM2.5 & $-0,35$ & 0,15 & $-0,05$ & $-0,55$ & 0,16 \\
\hline & PM10 & $-0,37$ & 0,12 & $-0,04$ & $-0,54$ & 0,13 \\
\hline
\end{tabular}

itations [18]. As mentioned earlier, the principles of airborne particulate matter reduction are specified in the Environmental Protection Law. Due to the lack of definition of low-stack emissions, municipalities and local governments have been arbitrarily implementing Low-Stack Emission Reduction Programs. The restrictions and bans on burning solid fuels in the process of heat production proved to be an example of primary actions [2]. Due to these limitations, residents of Kraków have receive grants for the replacement of inefficient solid-fuel stoves with more environmentally friendly heating solutions, e.g. gas, electric, oil or municipal heating systems. The program is also based on the use of renewable energy sources in the heating industry: heat pumps and solar thermal collectors $[10,18]$. As part of secondary activities limiting the emission of pollutants, buildings undergo thermal modernization in order to limit energy losses. It consists of thermal insulation of building partitions, as well as replacement of windows and doors with elements of appropriate technical parameters, while maintaining proper installation. Other important measures involve changing the heating source, ventilation systems and selecting correct stack parameters [2]. Dedusting systems which remove pollutants from flue gases also play an important role. Since transport is an important source of dust, a European emission standard has been introduced, which classifies vehicles according to the amount of pollutants emitted [16]. Another important pro-ecological action in transport is the expansion of public transport. Public buses use specially designated lanes, which allows them to travel several times faster in a crowded city. It should be noted that as part of its pro-ecological activities, the Municipal Tranportation Company in Kraków has 26 purchased low-emission electric buses manufactured by Solaris to run on its routes [19].

\section{Conclusions}

The analysis presented in the paper leads to the following conclusions:

- Weather has a significant impact on air quality, as confirmed by the high value of the Pearson linear correlation coefficient.

- Wind speed in the autumn and winter seasons has by far the greatest influence on air quality in al. Krasińskiego, in the Ruczaj and Kurdwanów dis- 
tricts. A strong negative correlation and a moderate negative correlation were displayed.

- In all districts, a moderate negative correlation or a strong negative correlation between particulate matter concentration and cloudiness were recorded in autumn.

- In the summer, a moderate negative correlation and a weak negative correlation between particulate matter concentration and air temperature were observed in all districts, which then changed into a moderate positive correlation and a weak positive correlation in autumn.

- For the summer period, a moderate positive correlation was observed between air humidity and particulate matter concentration in al. Krasińskiego and in Ruczaj.

The air in Kraków is one of the most polluted in Europe, which was confirmed by measurements taken by monitoring stations: in al. Krasińskiego, in Ruczaj and in Kurdwanów, where the average annual PM2.5 and PM10 particulate matter exceeded the permissible annual levels.

In connection with the current ban on burning solid fuels in Krakow, the so-called anti-smog resolution, and subsidies for the replacement of obsolete heating with more environmentally friendly solutions, the situation is slowly improving.
However, the inflow of pollution from the suburban areas, to which this ban does not apply, still creates significant nuisance for the agglomeration. The location of Kraków in a basin and the high level of air corridors [15], which further hinder ventilation, only strengthen the underlying issue. Air pollution causes a number of negative health effects within the society $[20,21,22]$. The most vulnerable groups are sick people, children, pregnant women and the elderly $[23,24]$. Nation-wide environmental education and increasing the level of environmental awareness among the residents of Kraków are key to achieving the goal of reducing air pollution. Environmental action consist of both preventive and remedial measures.

\section{Author Contributions:}

Maciej Ciepiela did the data collection, wrote the paper and result analysis. Wiktoria Sobczyk conceived, designed the search, wrote the paper and result analysis. Both authors have read and approved the final manuscript.

\section{Conflict of interest statement}

The authors declare no conflict of interest.

This paper was supported by AGH University of Science and Technology, Faculty of Mining and Geoengineering, al. Mickiewicza 30, 30-059, Krakow, Poland. 


\section{Literatura - References}

1. Commission Directive EU, 2015/1480 of 28 August 2015, amending several annexes to Directives 2004/107/EC and 2008/50/EC of the European Parliament and of the Council laying down the rules concerning reference methods, data validation and location of sampling points for the assessment of ambient air quality. Available online: https:// eur-lex.europa.eu/legal-content/EN/TXT/?uri=celex\%3A32015L1480 (accessed on 29 November 2020).

2. Kaczmarczyk, M., Kaczmarczyk, M., Pełka, G., Luboń, W., Będkowska, A., Ciapała, B., Malik, D., Podlewska, E. and Zboina, M. (2017). Low emission energy efficiency in communes and local governments. Globenergy, Kraków, 11118.

3. Act of September 10, 2015 amending the Act - Environmental Protection Law. Journal of Laws 2015, item 1593, Available online: https://isap.sejm.gov.pl/isap.nsf/DocDetails=WDU20150001593 (accessed on 29 November 2020).

4. Resolution No. XXXII/452/17 of the Lesser Poland Regional Assembly of 23 January 2017 on the introduction of restrictions and prohibitions in the area of the Małopolskie Voivodeship operation of installations in which fuel combustion takes place. Available online: https://www.google.com/search=Uchwa\%C5\%82a (accessed on 15 September 2020) (in Polish).

5. Marshal's Office of the Małopolska Region, Department of the Environment, Anti-smog resolution. Available online: https://powietrze.malopolska.pl/antysmogowa (accessed on 4 March 2020) (in Polish).

6. The Act of May 20, 2016 on energy efficiency. Journal of Laws 2016, item 831. Available online: https://isap.sejm. gov.pl/isap.nsf/DocDetails.xspd=WDU20160000831 (accessed on 15 September 2020) (in Polish).

7. Air quality standards defined for the annual air quality assessment. Available online: https://powietrze.gios.gov.pl/ pjp/content/annual_assessment_air_quality_info (accessed on 1 October 2020) (in Polish).

8. Regulation of the Minister of the Environment Concerning the Levels of Certain Substances in the Air of 8 October 2019. Item 1931. Journal of Laws 2019. Warszawa, Poland (in Polish).

9. Information on air quality standards for alert levels. Available online: http://powietrze.gios.gov.pl/pjp/content/annual_assessment_air_exposure_alarms_level_info (accessed on 15 September 2020) (in Polish).

10. Pałasz, J.W. (2016), Low emission from coal combustion and methods of its reduction. Ed. Silesian University of Technology, Gliwice, 13-104.

11. Borowski, G. and Malec, A. (2016), Dust hazards and air monitoring. Ecol. Engin, 50, 161-170.

12. Jędrak, J., Kondrucka, E., Badyda, J.A. and Dąbrowiecki, P. (2017), Krakow Smog Alert. The impact of air pollution on health, Kraków, 16-17.

13. Map of Krakow, www.targeo.pl

14. AccuWeather. Available online: https://www.accuweather.com/pl/pl/krakow.weather-forecast (accessed on $17 \mathrm{Sep}-$ tember 2018, 10 March 2019) (in Polish).

15. Sadlok, R. (ed.) (2014), Counteracting low emissions in dense residential areas. Association for energy efficiency and the development of renewable energy sources "Helios", Bochnia.

16. Bogacki, M., Oleniacz, R., Rzeszutek, M., Bździuch, P., Szulecka, A. and Gorzelnik, T. (2020), Assessing the impact of road traffic reorganization on air quality: a street canyon case study, Atmosph., 11 (7), 695, 1-23.

17. Sobczyk, W. (2002), Statistical methods in researching the ecological awareness of young people, Publishing and Consulting Agency Geo, Kraków, 64-93 (in Polish).

18. Marshal's Office of the Małopolska Region, Department of the Environment, Anti-smog Resolution. Available online: https://powietrze.malopolska.pl/antysmogowa (accessed on 4 March 2020) (in Polish).

19. Urban transport company, Spółka Akcyjna in Kraków: Electric buses. Available online: http://www.mpk.krakow.pl/ $\mathrm{pl} /$ tabor/autobusy-elektryczne (accessed on 22 March 2019) (in Polish).

20. Saramak, A. (2019), Comparative analysis of indoor and outdoor concentration of PM10 particulate matter on example of Cracow City Center. International Journal of Ennronmental Science and Technology, 16, 6609-6616.

21. Gruszecka-Kosowska, A. (2018), Assessment of the Kraków inhabitants' health risk caused by the exposure to inhalation of outdoor air contaminants. Stochastic Enrironmental Research and Risk Assessment, 32, 485-499.

22. Jachimowski, A., Paprocki, M. and Wojnarowska, M. (2018), Tackling Air Pollution in Kraków. E3S Web Conf. 44.

23. Kolasa-Więcek, A. and Suszanowicz, D. (2019), Air pollution in European countries and life expectancy - modelling with the use of neural network. Air Qual., Atmosph. \& Health, 12 (71), 1335-1345.

24. Suszanowicz, D. and Kolasa-Więcek, A. (2019), The impact of green roofs on the parameters of the environment in urban areas - review. Atmosph., 10 (12), 792, 1-8. 
Badanie stężeń PM 10, PM 2,5. w powietrzu atmosferycznym w Krakowie, Polska

Krakowskie powietrze jest jednym $z$ najbardziej zanieczyszczonych $w$ Europie. Polskie normy poziomów informowania oraz alarmowego dla pyłu zawieszonego PM10 sa najwyższe w Europie i kilkakrotnie przekraczaja zalecenia Światowej Organizacji Zdrowia (WHO) w odniesieniu do bezpiecznych stężeń dobowych. W artykule przedstawiono wyniki pomiarów zapylenia powietrza $w$ trzech dzielnicach Krakowa. Badania wykazaly, że stężenie pyłów zawieszonych PM2.5 i PM10 przekroczyty średnioroczne poziomy dopuszczalne. Pomiary empiryczne PM2.5 przedstawiaja znacznie wyższe wartości zanieczyszczenia niż dane ze stacjonarnych stacji monitoringu na dwóch stanowiskach. Wysoka wartość wspótczynnika korelacji liniowej Pearsona potwierdza, że warunki pogodowe maja istotny wplyw na jakość powietrza w Krakowie. Zdecydowanie największy wplyw na jakość powietrza ma prędkość wiatru w okresach: jesiennym i zimowym na al. Krasińskiego, na Ruczaju i na Kurdwanowie. Wykazano znaczącą odwrotną zależność. Pomiary manualne należy stosować $w$ charakterze weryfikacji danych ze stacji monitoringu powietrza. Należy się spodziewać, że na terenie Krakowa czystość powietrza będzie się poprawiać w zwiazku z obowiązująca uchwata antysmogowa oraz dotacjami na wymianę ogrzewania na bardziej przyjazne środowisku.

Słowa kluczowe: czastki pyłowe, jakość powietrza, zanieczyszczenie, Kraków 